\title{
実験データに基づく設計支援技術 〜マルチスプライン応答曲面法の提案〜
}

\begin{abstract}
Design Support Technology based on Experimental Data
- Proposal of Response Surface Methodology by Multi-spline -
\end{abstract}

綛田 長生（山武）

Chosei KASEDA, Yamatake Corporation

Key Words: RSM, Thin-plate spline, pharmaceutical design food design

\section{論文要旨}

\begin{abstract}
近年の製品/生産設計の高効率化要求に対し, 学術界・産業界において, 様々な取り組 みがなされており, 実験デー夕に基づく設計支援技術の 1 つとして応答曲面法が注目さ れている. 本報では著者の提案手法による設計事例を紹介するとともに，近似最適化技 術の 1 つである応答曲面法の実用的課題について議論する.
\end{abstract}

\section{1. 緒言}

近年の顧客ニーズの多様化, 市場競争の激化により, 品質, 納期に対する市場要求は益々厳しくなり,ニーズにあわせた 製品の迅速な市場投入が要求されている。このため, 製品設 計業務の高効率化要求は益々高まってきている，また，昨今 の消費低迷，中国などからの安価な製品参入のため，コスト 削減の要求も厳しくなっており，開発コスト削減の要求も 益々高まっている1).

製品設計業務においては，Fig.1 に示したように詳細設計 $\rightarrow$ 試作評価 設計修正を繰り返す（時には試行錯誤的に繰り 返す)ことにより，多くのコストが必要となることは広く知 られている2)。この課題に対し, 有限要素法などのシミュレ ーション技術により試作をなるべく行わず，計算機上で試作 評価を実行することで設計業務を効率化する試み，つまり C A E (Computer Aided Engineering) が産業界で広く行われて いる3). また，自動車業界を中心に，モデルベース開発 (Model-Based Development；MBD）の取り組みが盛んに行 われ，主に制御系設計で成果を出している4).

しかし，このような取り組みでは，物理法則に基づく何ら かのモデルが必要となるが, 対象によっては物理モデルの構 築が困難な場合がある. 本報で取り上げている製薬設計や食 品設計などが代表的な例である。このような場合，実験デー タをもとに，統計モデル（近似モデル）を構築し，その近似 モデルを利用して最適設計を行うアプローチをとることが ある.また，多数のサブシステムの融合体である自動車など の場合は，すべての対象を物理モデル化することが困難なこ とがあり，物理モデルと統計モデル（近似モデル）を融合し て利用するアプローチも有効である.

実験データに基づく近似モデルにより最適設計を行う手 法は, 応答曲面法と呼ばれるフレームワークとして広く知ら れている5 . 近年, 産業界においては, 様々な対象に対し, 適用され成果を出している67).

一方で，応答曲面法のスキームを利用して，これまでに設 計経験のない全く新しい対象を取り扱う場合には, いくつか の実用上の課題が残ると筆者は考える.

本報では，応答曲面法の実用上課題を解決する手段として 考案した手法を提案し，提案手法を実際の製品設計問題に適 用した事例を紹介する．また，これらの適用事例の紹介を通
し，近似モデルを利用した設計支援技術を広く産業応用する 場合の実用上の課題と今後の展望を整理したい.

なお，医薬品設計においては，日米EU医薬品規制調和国 際会議の製剂開発ガイドラインICH Q8 の考え方が浸透して きており，設計の科学的根拠が求められてきている ${ }^{8)}$ 。経験 や勘に頼らない設計として，今後もさらに応答曲面法などの 品質工学的なアプローチの重要性が増すと考える.

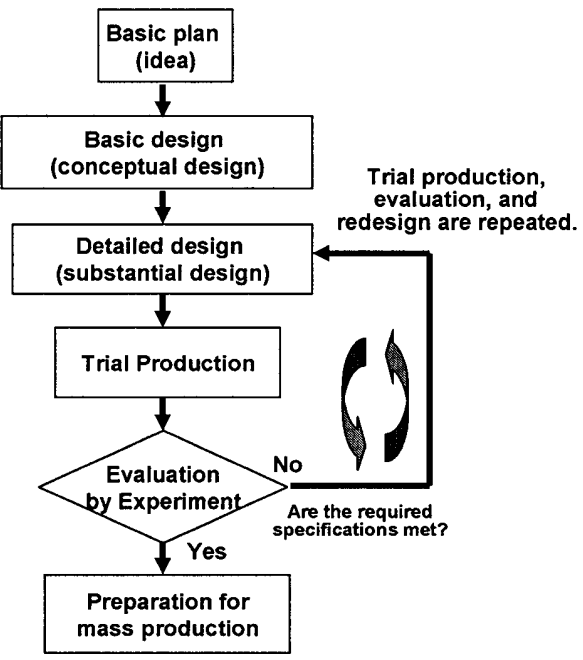

Fig.1. Basic flow of product design work

\section{2. 応答曲面法の実用上課題}

少ない実験デー夕をもとに最適設計条件を探索するため の方法論である応答曲面法では, 一般的には以下の 3 つのス テップで最適設計が実施される5).

\section{Step1；実験データ収集}

一般的には，実験計画法に従い，なるべく少ない実験 回数となるよう実験配置を決定し，実験データを収集す る。ここでは，実験対象の特性や，次ステップである応 答曲面モデル（統計モデル）構築を勘案し, 直交計画, 球形中心二次複合計画など実験配置を決定する. 
Step2 ; 忘答曲面モデル作成

前ステップで収集された実験データをもとに，応答 曲面モデルを構築する. 通常, モデル化対象の線形性 が強い場合は多項式近似（統計近似）が，また非線形 性が強い場合は，ニューラルネットワーク $(\mathrm{NN})$ のよう な所謂ブラックボックスモデリングが利用される ${ }^{9)}$.

\section{Step3 ; 最適値探索}

応答曲面モデルを目的関数 (評価関数) として利用し て, 最適值探索を実施し, 最適設計条件を決定する，産 業界では，この最適化問題が非線形計画問題となること が多く, 逐次二次計画法や，GAなどのヒューリスティッ クな最適化手法が一般的に利用されている6)

上記応答曲面法は, 実験を主体とする設計業務に有効なア プローチである. しかし一方で, 試作実験をべースとするが 故に次のような実用上の課題があると筆者は考える。

課題 (1)；理想的な実験計画データの収集が困難

これまでに筆者が関わった, 製薬業界, 食品業界などでは, 実験計画的なデータ収集がコスト的に，また設備制約上，許 されない場合がある。

製薬業界では，実験に使用する試薬が高価なことから，1 回の試作実験で数百万円のコストがかかる場合があり，最適 設計のために収集できる実験デー夕数は他事例に比べ, 極端 に少なくなることが多い，そのため，例えば実験系を組みな おしながら，すべての実験計画データを繰り返し収集し直す ようなアプローチをとることが困難な場合がある.

また，実験設備としての制約があり，均等な実験配置を実 施できるとは限らず，また奏験を奏行できない条件などもあ り，不均等な実験配置となることも多い

これらの課題は, 部分的にでも物理モデルを利用したアプ ローチが取れる対象であれば, CAE との併用により, 解決す ることは可能であるが, 物理モデルの構築が困難な場合には, この少なく，均等配置ではない実験データをべースとして， 最適設計をせざるを得ないことが害用上多い.

課題 (2); 応答曲面モデル構築の工数大

主に，上記実験データを利用することに起因し，とくに不 均等な実験データ配置に起因し, 応答曲面モデルの構築が試 行錯誤的になり，多大な工数がかかることがある.

機械設計の場合とは異なり, 薬品や食品などの対象の場合, ほとんどが非線形現象である。このため, 多項式近似を利用 する場合には,なんらかの非線形項 (べき乗関数, 指数関数, ロジスティック関数など) の導入により, 非線形回帰を実施 する必要がある。この場合, 多数の項を組み合わせ, 近似式 を試行錯誤的に構築することとなる.またニューラルネット ワークなどブラックボックスモデリング手法を利用するこ とも考えられるが, モデリングのためのチューニングパラメ 一タがあり，このパラメータの決定方法に指針があまりない ために，統計モデル構築と同様に試行錯誤的な作業となって しまい，モデル構築に多大な工数が必要となることがある. 本来, 設計作業の効率化を図るために利用するはずの忘答曲 面法の利用により，試行錯誤の作業が必要となるのは，本末 転倒であると考える。

課題（3）；応答曲面モデルの品質のばらつき（再現性）

上記モデル構築の課題に起因し, 同一の実験データを利用 しているにも関わらず, 設計者により応答曲面モデルの品質 がばらつくことがある.これにより設計結果にもばらつきが 生じてしまう。つまり，モデル構築には前述 2）の課題があ ることから, 設計者の応答曲面モデル構築のスキルに依存し て設計結果が大きく変化してしまうことがある.設計条件決
定には, 設計者の知識が入るため最終的な設計結果にばらつ きがあることは否めないが，これがモデルの出来，不出来に 大きく起因することは課題であると考える.

前述の課題は，製薬・食品などの物理モデルで表現できな い現象を取り扱う場合に顕著となる課題であるが，他の業界 においても同様に課題となることがあると考える.

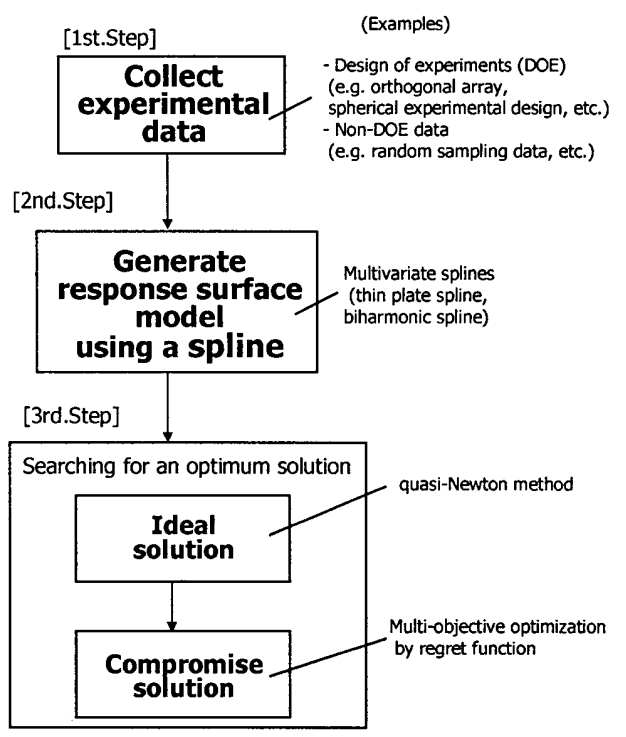

Fig.2 Proposed RSM using multi-spline

\section{3. マルチスプライン応答曲面法の提案}

前述の課題を解決する手法として，マルチスプラインを利 用した応答曲面法 (RSM-S ; Response Surface Method by Spline）を提案する.

Fig.2 に本手法の処理の流れを示す．本手法は，従来の応 答曲面法と同様に，3つのステップからなるが，前述の課題 を解決するべく，応答曲面生成のために次式で示すマルチス プライン（薄板スプライン）を利用する.

$$
f(x)=\sum_{i=1}^{n} \alpha_{i} g\left(d_{i}\right)+\sum_{j=1}^{p} c_{j} x_{j}+c_{0}
$$

$\alpha_{i}, \mathrm{c}_{j}$ 係数, $p$ は入力変数 $x$ の次元数, $n$ はデータ数, $d_{i}$ はあ るデータ $i$ と任意の $x$ 座標とのユークリッド距離, $g\left(d_{i}\right)$ はグリ ーン関数.

なお, 式(1)は以下の式(2)で表現される屈曲エネルギー $E$ の最小化問題を離散化して解くことで導出される ${ }^{10}$.

$$
E=\lambda \cdot \int_{S}\left(\nabla^{2} f(\mathbf{x})\right)^{2} d S+\frac{1}{n} \sum_{i=1}^{n}\left(f(\mathbf{x})-y_{i}\right)^{2}
$$

本提案手法では，この薄板スプラインの利用により，前述 の 3 つの課題を解決している．以下にこれを説明する.

薄板スプラインはリモートセンシングや形態解析などの 分野で利用されているスプラインであり, ランダムサンプリ ングされたデータから，滑らかな 3 次元形状を再現する目的 で利用されている. 一方，薄板スプラインの基本となる式(2) は多次元への拡張が容易であり，これを $n$ 次元に拡張してス プライン関数を導出することで, 多要因の設計問題への応用 が可能となる。これにより, 従来よりも, デー夕配置の偏在 にロバストな応答曲面生成が可能となり，必ずしも理想的な 実験計画データでなくても滑らかな応答曲面の生成が容易 となる (課題（1）の解決).

式(1)の薄板スプラインにおける係数 $\alpha_{i}$, $\mathrm{c}_{\mathrm{j}}$ は, 入出力空間 のサンプリングされたデータマトリクスから, 線形行列演算 
で算出することができる，つまり，式(1)を利用することで， 収集した実験データから，応答曲面を一意に決めることがで きる。これにより，試行錯誤的なモデリングが不要となり， かつ，データが同じであれば，再現性のある忘答曲面が生成 できる(課題（2）（3）の解決）。

以上のように, 本提案手法では, 薄板スプラインの利用に より, 柔軟で迅速な応答曲面生成を可能とし, 応答曲面法を 利用した設計業務の効率化を図っている. 設計者にとっては, 必ずしも理想的な実験計画データでなくても，応答曲面をす ばやく生成することができる利点がある，つまり，設計者の モデリングのスキルに依存することなく，設計検討作業に注 カできることとなる.

なお，ここでは対象として想定している製薬設計，食品設 計問題では, 設計対象は設計条件に対し, 非線形ではあるが, 単調増加，単調減少であることが多いため，外挿領域に近い 端面でも応答曲面全体の傾斜を維持できる薄板スプライン が有効であると考える.これは, 式(1)に示したように薄板ス プラインには線形近似項を含むため, 外挿近傍での不必要な 曲がりが少ないためである゙11).

また，本手法では，Fig.2 に示したように，現実の設計問 題を考慮し，多目的最適化機能を備えた。ここでは，式(3) に示す距離関数 $f(x)$ を評価関数として利用することで, 多目 的最適化を行う。

$$
\min _{x} f(x), \text { where } f(x)=\sum_{i} w_{i}\left(\frac{y_{i}(x)-\hat{y}_{i}}{r_{i}}\right)^{2}
$$

$x$ は設計変数, $w_{i}$ は重み係数, $y_{i}$ は特性值, $\hat{y}_{i}$ は事前に探 索した特性值の最大值または最小值 (理想値と呼ぶ)， $r_{i}$ は事 前に探索した特性值の最大值と最小值の差 (レンジ)である。 添字 $i$ は, 最大化または最小化したい特性值が，複数あるこ とを表している。

なお，設計対象として目標スペック（希望する特性の上下 限値, 目標数値）がある場合には，以下の式(4)を評価関数と して利用する。

$$
\begin{array}{r}
\min _{x} g(x), \text { where } g(x)=\sum_{i} w_{i}\left(\frac{y_{i}(x)-\hat{y}_{i}}{r_{i}}\right)^{2}+L(x)+U(x) \\
L(x)=\left\{\begin{array}{c}
0,\left\{x: y_{j}(x) \geq \underline{y_{j}}\right\} \\
\sum_{j} p_{j}\left(\frac{y_{j}(x)-y_{j}}{r_{j}}\right)^{2},\left\{x: y_{j}(x)<\underline{y_{j}}\right\}
\end{array}\right. \\
U(x)=\left\{\begin{array}{cc}
0,\left\{x: y_{k}(x) \leq \overline{y_{k}}\right\} \\
\sum_{k} p_{k}\left(\frac{y_{k}(x)-\overline{y_{k}}}{r_{k}}\right)^{2},\left\{x: y_{k}(x)>\overline{y_{k}}\right\}
\end{array}\right.
\end{array}
$$

$w_{i}, p_{j}, p_{k}$ は重み係数, $y_{i}, y_{j}, y_{k}$ は特性值, $r_{i}, r_{j}, r_{k}$ は事前に 探索した特性値の最大值と最小值の差 (レンジ). $\hat{y}_{i}$ は事前 探索した特性值の最大值または最小值，または希望値.

は特性値の下限値. $\overline{y_{k}}$ は特性值の上限値.

なお，ここでは，製造上の制約などがあり，設計条件とし て制限がある場合を加味し，また，忘答曲面の外挿領域を探 索しないよう，制約付き最適化を行うものとする.

実務上，設計を実施する際には，ターゲットスペックが想 定されている場合が多く，上記評価関数；式(4)を利用するケ 一スが多い，例えば，製剂設計においては，特許切れ先発医 薬品を他社があらためて同等性能の製剤を設計する(ジェネ リック医薬品設計）場合などに有効である.

また，設計支援システムとしては，可視化機能を充実させ， 設計者が設計対象の特性を容易に理解できるようにした。設 計対象が未知であるが故に，応答曲面による可視化は有効で あると考える，さらに，製薬・食品だけでなく，広く産業界
で利用できるように汎用的な設計支援システムとしている.

\section{4. ケーススタディ}

前章で提案した応答曲面法を，様々な設計対象に適用した 事例を紹介するとともに，本手法の有効性を示す。

\section{4-1 製剂設計の事例}

以下に医薬品製剤設計に適用した事例を紹介寸る。この事 例は，主薬（テオフィリンと呼ばれる気管支搪張剤）が錠剤 から溶け出す速度（溶出プロファイル;Fig.3）を最適化する ために，添加剤の配合と製造条件を設計した例である.

主薬であるテオフィリンを $100 \mathrm{mg}$ とし，添加剤であるゲル 化剤および崩壊剤をそれぞれ 250mg〜 750mg, 0〜250mg変化 させ，かつ製造条件である打錠圧も50～ $250 \mathrm{kgf} / \mathrm{cm}^{2}$ 変化させ て，複数のサンプル錠剤を製造し，溶出実験を実施した。 こ こでは, Fig.3 に示した溶出プロファイルを測定し, 溶出特 性を数値化している. 溶出プロファイルは以下の理論式(5) で表現できることが分かっている゙'ため, 実験データから下 記指標 $W_{f 0}, k_{f}, k_{s}$ を算出し, これを目的变数（特性値）とし て利用している。

$$
C=100-\left\{W_{f 0} \exp \left(-k_{f} t\right)+\left(100-W_{f 0}\right) \exp \left(-k_{s} t\right)\right\}
$$

$C$ は主薬の溶出率, $W_{f 0}$ は初期溶出率, $k_{f}$ は前期溶出速度であ $\eta$, 速放性（寸ばやく溶ける）の指標, $k_{s}$ は後期溶出速度で あり，徐放性（持続する）の指標を表す.

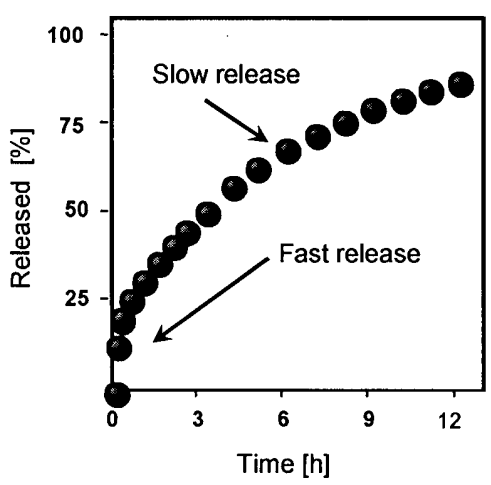

Fig.3 Example of tablet-release-profile

ここでは，即効性（速放性）があり，かつ持続性（徐放性） の優れた錠剂，つまり，すぐ効いて効き目が持続する錠剤と なるよう，添加剤（ゲル化剂および崩壊鼡）の配合条件およ び製造条件（打錠圧）を設計している. 結果を Fig.4 に示す. Fig.4 (a)〜 (c)は, $3 つ の$ 特性ごとの応答曲面であり, 図中赤 で示した点は各特性の実験範囲内における理想值である.つ まり，(a)初期溶出率では最小值，(b)前期溶出速度では最大 值, (c)後期溶出速度では最小值となる. 図より, (a)初期溶出 率と (c)後期溶出速度の応答曲面における理想解では同様な 設計条件となっているが，(b)前期溶出速度の応答曲面におい ては，全く異なる設計条件が理想解となっている.また，こ れらはトレードオフの関係にあることが分かる。このため, (a),(b),(c)において同時に成立するような現実解，つまり妥協 解として，(d)に示す汎距離関数を最小にする条件 (緑で示し た点）が本手法により見出された.

本設計問題に対し，ニューラルネットワークを適用すると， 特性を表現する応答曲面を構筑するために数時間かかる場 合があった ${ }^{9)}$ が, 提案手法を適用することで, 瞬時に設計が 行え, 本手法が設計効率の改善に有効であることが示唆され た.

なおここで用いた実験データは，球形中心二次複合計画 に従い収集されており，実験データ数，つまりサンプル数と 
しては 16 サンプルである.また, Fig.4 の忘答曲面は, 図に 示されていない設計変数である打錠圧を最適条件; 147.36 kgf に固定した場合の断面を表している.

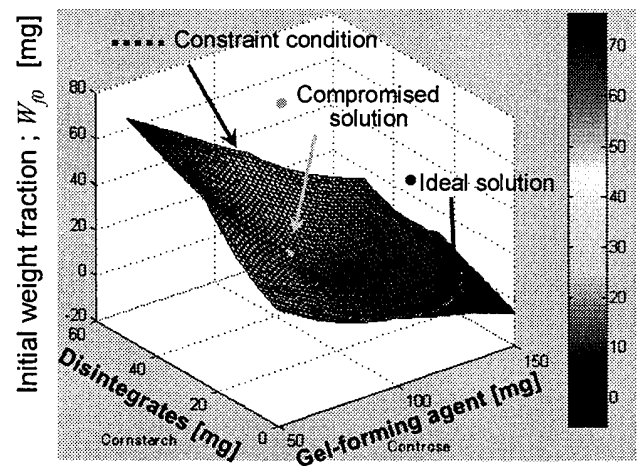

(a) Initial weight fraction of fast phase ; $W_{f 0}$

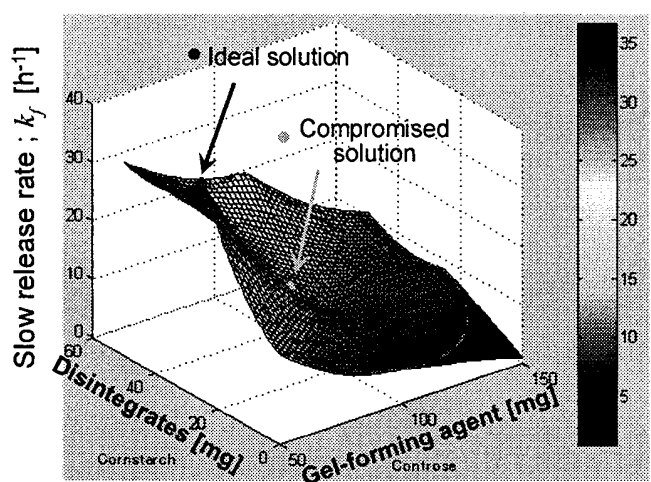

(b) Fast release rate ; $k_{f}$

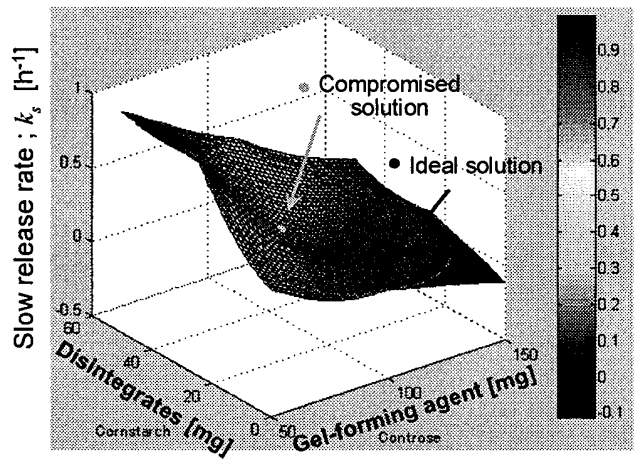

(c) Slow release rate ; $k_{s}$

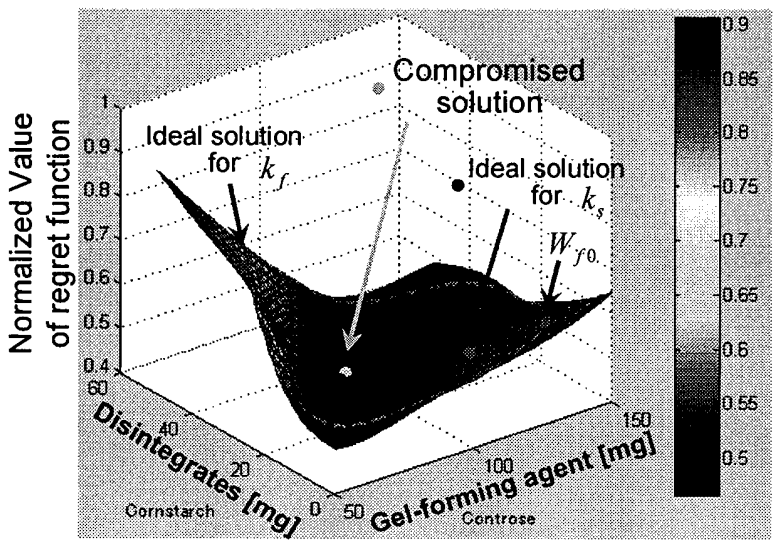

(d) Regret function

Fig.4 Results of tablet formulation (mixing rate design for drug)

\section{4-2 食品設計の事例}

次に，食品設計に適用した事例を紹介する。この例はイン スタントコーヒーの製造条件である凍結乾燥条件の設計問 題である.ここでは，インスタントコーヒーがコーヒー原液 と同等なアロマ成分（香気成分）となるよう，つまり目標ス ペックに近づけるべく，製造条件を最適化している.

特性值となるアロマ成分の定量化には，ガスクロマトグラ フ質量分析(GC/MS)が通常利用されているが，コーヒーアロ マのような微量成分の検出や香りの特徽を把握することは 困難であったため, ヒトの臭覚器官を検知器として併用する $\mathrm{GC} / \mathrm{Olfactometry}(\mathrm{GC} / \mathrm{O})$ を利用した。この方法により, 機器分 析だけでは検出できないアロマの特徽および強度の数值化 を実施している. Fig.5にGC/Oの概念図を示す. GC/Oではガ スクロマトグラフで分離された成分の匂いをパネラーが嗅 ぎ，そのアロマ成分の特徵と知覚可能時間を記録する. 香気 の強度 $C V$ は次式で定義される ${ }^{12)}$

$$
C V=\int_{\text {peak }} F^{n-1} d i
$$

Fは希釈率，nは希釈回数であり， $\mathrm{F}^{\mathrm{n}-1}$ は各成分の香気に及ぼ す影響度を意味する。香気強度CVは，パネラーがその成分

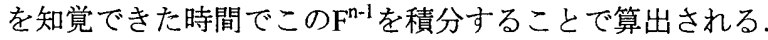

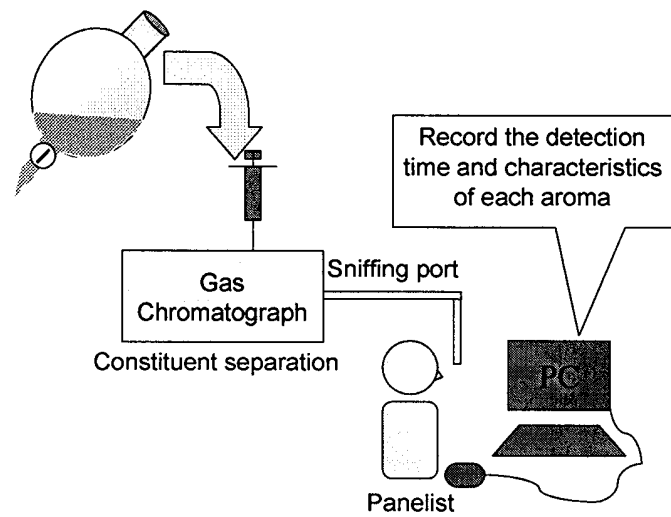

Fig.5 Schematic of GC/O analysis

実験では, コーヒ一溶液に対し, 凍結温度を $-120^{\circ} \mathrm{C} \sim-40^{\circ} \mathrm{C}$, 乾燥温度を $25^{\circ} \mathrm{C} \sim 80^{\circ} \mathrm{C}$ 変化させ，サンプルを製造した後， コーヒーアロマの各成分について, 香気強度を計測した。実 験データの例を Fig.6 に示す. Fig.6 は乾燥温度を $80^{\circ} \mathrm{C}$ とし, 凍結温度を変化させた場合に, 各アロマの強度がどのように 変化しているかを示している. また，下図では目標スペック となるコーヒ一原液のアロマを緑線で示している. 下図より, 乾燥温度を $80^{\circ} \mathrm{C}$ とた場合には, 凍結温度に関わらず, 目標 スペックであるコーヒー原液のアロマ特性に対し，サンプル 製造品のアロマ特性が㓞離していることが分かる.

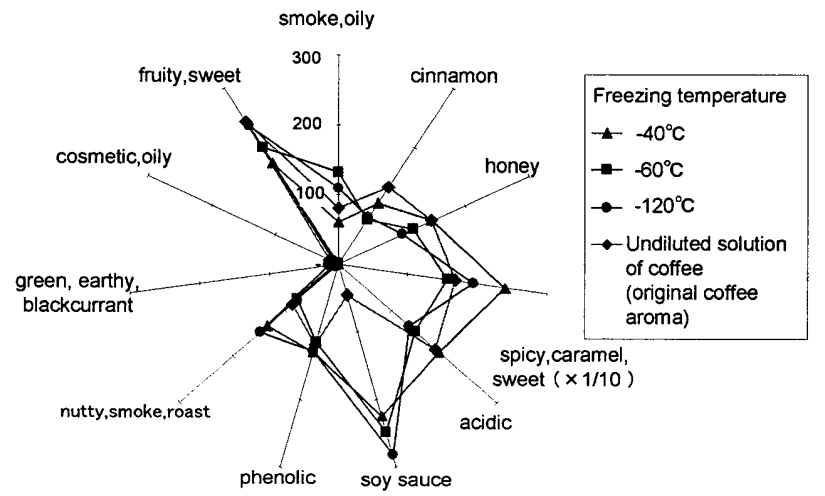

Fig.6 Aroma profile at various freezing temperatures and the drying temperature: $80^{\circ} \mathrm{C}$ 
これらの実験データに本提案手法を適用し，凍結乾燥条件 の設計を行った。ここでは，目標スペックをコーヒ一原液の 香気強度であるとし, 凍結乾燥後のインスタントコーヒーが コーヒ一原液と同様なアロマ特性となるような, 凍結温度お よび乾燥温度を探索した。

結果を Fig.7 に示す. (a)はアロマ特性と製造条件の関係を 表す応答曲面の 1 例であり，(b)は最適条件として探索され た, 凍結温度 $-40^{\circ} \mathrm{C}$, 乾燥温度 $31.8^{\circ} \mathrm{C}$ におけるアロマ特性を 示している. (b)中の青線は, 本提案手法で推定された最適設 計条件におけるアロマ特性を表す，また，赤線は提案手法で 算出された設計条件 (凍結温度 $-40^{\circ} \mathrm{C}$, 乾燥温度 $31.8^{\circ} \mathrm{C}$ ) で あらためてテスト製造した場合のアロマ特性の実測值を示 しており, 推定されたアロマ特性と同等な特性であったこと が分かる。

つまり，本適用事例では，本提案手法により，目標スペッ クであるコーヒ一原液のアロマ特性と同等なインスタント コーヒー製造条件が適切に見出されたことから, 本手法の多 目的最適化機能の有効性を示唆していると考える.

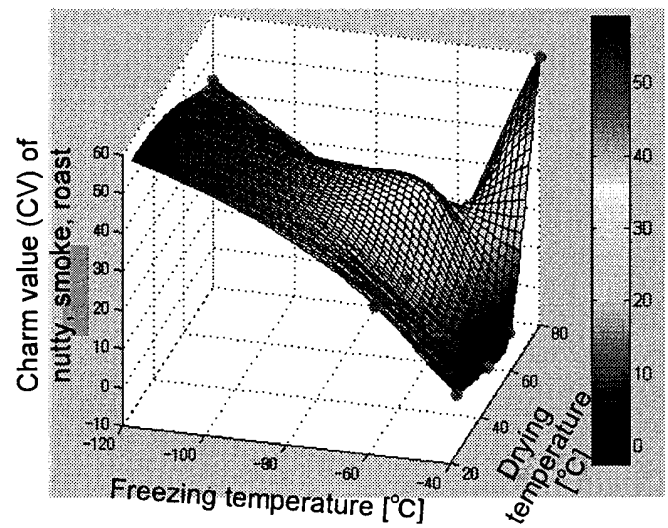

(a)Example of aroma-response-surface

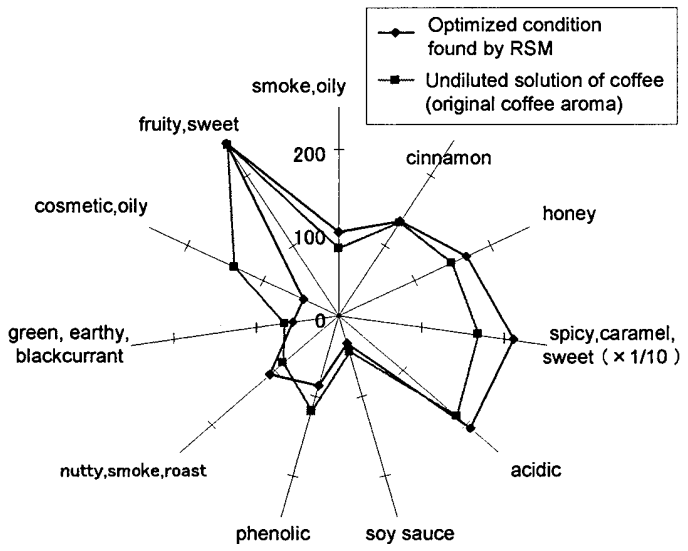

(b)Validation result of optimized condition by the RSM

Fig.7 Results of coffee aroma design

\section{4-3 放電設計の事例}

産業界においては，製薬，食品以外にも，物理モデルによ るアプローチをとることができない対象がある．その 1 例と して，放電機器設計の事例を以下に紹介する.

この事例は放電機器をある工場 $\mathrm{A}$ から別の工場 $\mathrm{B}$ に製造 移管した際に，設計条件の見直しを行ったものである．移管 先工場 Bで以前と同じ条件で製造したところ，不良品が多発 したため，設計条件の見直しを実施した。早急に解決する必 要性があったため, 短期間での検討を要求されていた．その
ため, 物理的検討のアプローチと併行して，実験的アプロー チにより，設計の見直しを実施した。

結果を Fig.8 に示す. ここでは, 放電機器の忘答速度を早 くし, かつ誤作動回数を減らすため, 放電機器に封入する 2 種類のガスの分圧条件の見直しを実施した。

Fig.8(a)が 2 種類のガスの分圧条件と応答速度の関係を表 す応答曲面, Fig.8(b)がガス分圧と誤作動回数の関係を表す応 答曲面である.また図中の黄色で示した点が以前の工場 Aの 条件のままで, 移管先工場 Bで製造した際の結果を示してお り，緑で示した点が本提案手法で最適化された設計条件であ る. Fig.8 より，以前の設計条件のままで製造したときにく らべ，見直し後の設計条件で製造すると，誤作動回数を増加 させることなく，応答速度が向上していることが分かる.

なお，本適用事例では，予め不具合の原因特定を行い，設 計変数を 2 つに絞り込んでいたため, Fig.8 のように設計対 象を可視化することができた。これにより，設計部門と製造 部門で理論的分析および実験的分析を効率よく進めること ができた．以上のことは，本提案手法を組み込んだシステム の可視化機能が有効であったことを示唆している.

\section{5. 結言}

本報では，近似最適化技術の 1 つである応答曲面法の実用 的課題について考察し，これらを解決する手法として，マル チスプラインを利用した応答曲面法を提案した。 また，提案 手法を実際の製品設計問題に適用した事例を紹介した. 本報 では，製薬，食品分野を中心に紹介したが，本手法は汎用的 手法であるため, 各産業分野において存在する試作実験を伴 う設計問題に広く適用可能であると考える. また，本提案手 法は，実用的課題の一部である，実験デー夕配置の問題とそ れに伴うモデリング作業の効率化の課題解決に貢献しうる 1 手法であると考える.

なお，上記以外にも以下のような実用上の課題はあるが， 今後も下記のような視点で, より一層の技術のブラッシュア ップを行い, 試作実験を伴う設計問題に利用可能な要素技術 の研究を継続する予定である。

・ 本提案手法では, 予めある程度の要因の絞込みが必要之 なる. 稀少な実験データでの効率的な要因分析手段が別 途必要と考える.

・本提案手法は，実験データの配置（偏在）にロバストで あるが，どの程度まで許容できるか定量的に評価できて いない. 実験デー夕配置の定量的評価手法を確立し, 配 置の再検討を支援する技術が必要と考える.とくに実用 上は，追加実験のための指針が有効と考える.

・ 4.1 節で示した時系列プロファイルを設計する問題に柔 軟に対応できるようにするため，時系列プロファイルの 形状を文献13)などの数值化技術を利用し，取り扱える ような工夫が必要である。

・実験データには計測誤差が含まれる．そのため，応答曲 面モデルとして, 計測誤差の偏在を考慮したモデル ${ }^{14) か ゙ ~}$ 必要であると考える．また最適解の信頼性を評価する手 法も必要である。とくに，医薬品開発においては，デザ インスペースの考え方が浸透しており，最適条件を信頼 性・安定性を考虑した最適空間として捉える手段 ${ }^{15) 16) の ~}$ 更なる検討が必要である.

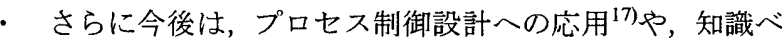
一スとの融合，質的データの取り扱い，物理モデルとの 融合なども検討する予定である.

\section{謝辞}

本研究を実施するにあたり，貴重なご助言と多大なご協力 をいただいた星薬科大薬剤学教室 高山教授, 東京大学農学 
生命科学研究科 相良名誉教授, 放電機器開発メ一力関倸者 各位に,この場を借りて感謝の意を表します。

\section{参考文献}

1) 林利弘，開発・設計プロセス工学技術とその展開，精密工学会 誌 Vol.72, No.12, pp.1442-1445 (2006)

2) 中沢弘, 「開発設計工学」, 工業調查会 (2002)

3) 竹岡修史, 天坂格郎，車両開発における C A E の現状と今後の 展望一超短期開発に向けた C A E の活用一，日本品質管理学会 研究発表会研究発表要旨集, Vol.80,pp.103-106 (2006)ほ加

4) 嶋田敏，モデルベース開発に向けた JMAAB 活動紹介，計測と 制御 Vol.47, No.3 (2008)

5) R.H. Myers, D.C. Montgomery, Response Surface Methodology, Wiley Series in Probability and Statistics (1995)

6) 䡣章, R.T.Haftka：「積層パラメータを変数とした座屈荷重応答 曲面を用いた遺伝的アルゴリズムによる複合材料積層構成最 適化」，日本機械学会論文集(A 編), 64-621, pp.1138-1145 (1998)

7) 吉野睦，仁科健，SQC とデジタルェンジニアリング 一設計パ ラメータ最適化の技術動向と今日的課題一, デンソーテクニカ ルレビューVol.10, No.1, pp.106-114 (2005)

8) 山原弘, ICH Q8 に関する最新動向 製剂開発の今後の展望も 踏まえて, Pharm Tech Japan Vol.23 No.12 (2007),

9) K. Takayama, A. Morva, M. Fujikawa, Y. Hattori, Y. Obata, and T. Nagai, Formula optimization of theophylline controlled-release tablet based on artificial neural networks, Journal of Controlled Release 68 , pp.175-186 (2000)
10) G. Wahba, Spline Models for Observational Data, Society for Industrial and Applied Mathematics, (1990)

11) C. Kaseda, The Practical Study on Response Surface Methodology, JSM 2004 Proceeding, pp.2128-2134 (2004)

12) Yasuyuki Sagara, Koji Kaminishi, Eri Goto, Taketoshi Watanabe, Yuriko Imayoshi, Hisakatsu Iwabuchi, Characteristic Evaluation for Volatile Components of Soluble Coffe Depending on Freeze-Drying Conditions, Drying Technology, 23(9-11), pp.2185-2196 (2005)

13) T. Kashima, Anomaly Detection Using Average Normal Profile of Time-Series Process Data， AEC/APC Symposium Asia 2009（査読 中)

14）西口純也, 綛田長生, 中山弘隆, 荒川雅生, 尹禮分, サポートベ クトル回帰を用いた実用的な外九值検出方法，第 52 回システ 么制御情報学会研究発表講演会予稿集, pp.781-782 (2008)

15) Arai, H., Suzuki, T., Kaseda, C., Ohyama, K., Takayama, K., Bootstrap re-sampling technique to evaluate the optimal formulation of theophylline tablets predicted by non-linear response surface method incorporating multivariate spline interpolation, Chem. Pharm Bull. 55(4), 586-593.(2007)

16) Arai, H., Suzuki, T., Kaseda, C., Takayama, K., Effect of an experimental design for evaluating the nonlinear optimal formulation of theophylline tablets using a bootstrap resampling technique, Chem. Pharm. Bull. 57(6), 572-579 (2009).

17）綛田長生，応答曲面法による最適設計支援技術とプロセス制御 一の応用, 第 52 回システム制御情報学会研究発表講演会予稿 集, pp.679-680 (2008)

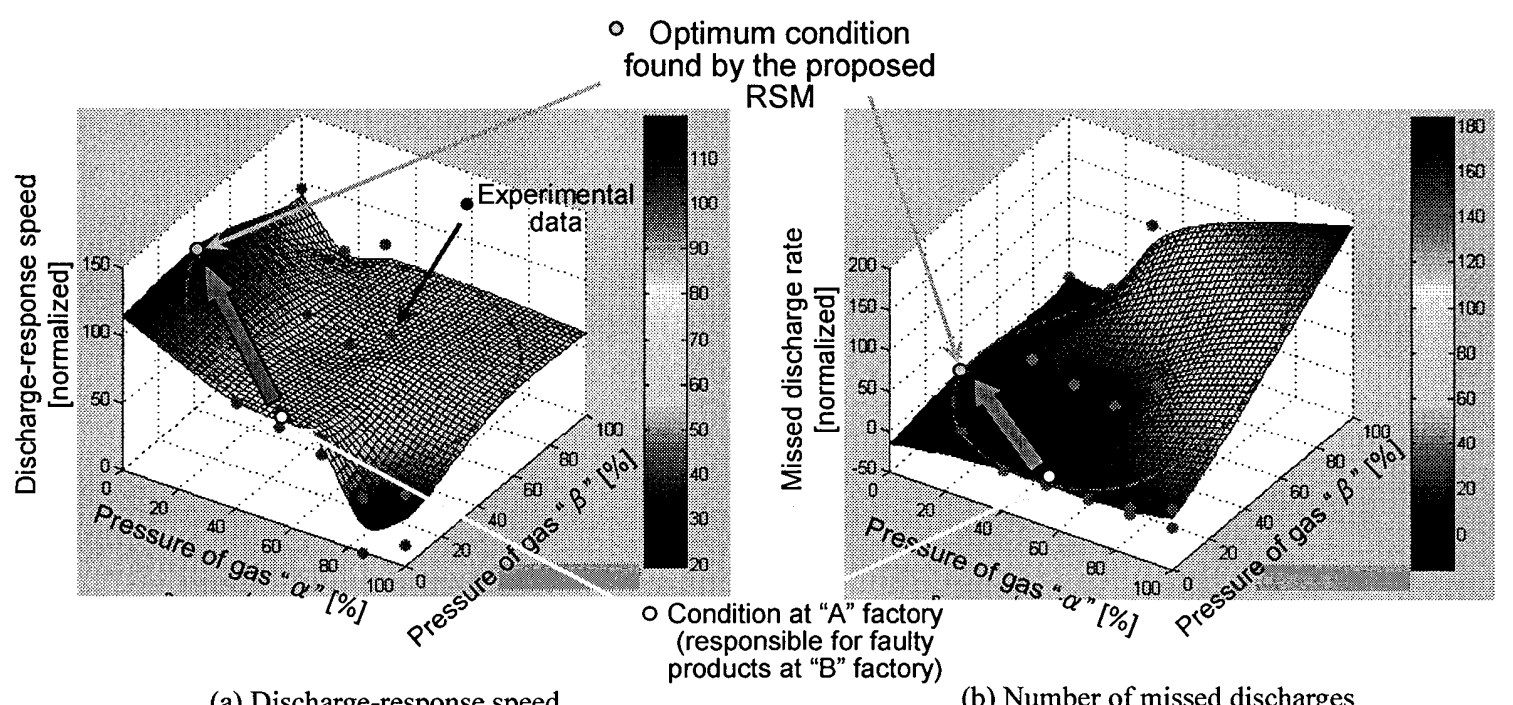

(a) Discharge-response speed

(b) Number of missed discharges

Fig. 8 Results of electrical device design 